\title{
Luke Feast
}

\section{In proportion}

\author{
Analysing New Zealand's constitutional system
}

\begin{abstract}
Avoiding the worst impacts of global warming is a matter of systemic change and political will. An easily adaptable political system would be resilient to the effects of climate change, since a government could maintain effective control by implementing incremental changes. However, except for the United Kingdom (UK), Israel and New Zealand, all other states have rigid codified constitutions. Drawing on cybernetics and variety engineering, the study of New Zealand's constitutional system presented in this article suggests that a rigid codified constitution has merits for addressing long-term problems, such as climate change and sustainable development.
\end{abstract}

Keywords: constitutions, democracy, systemic design, variety engineering, climate change

\section{Introduction}

While the climate crisis is the most complex challenge that homo sapiens have ever faced, the solution is so simple that anyone can understand it. We must stop emissions of greenhouse gases. In 2017, human-induced global warming reached approximately $1{ }^{\circ} \mathrm{C}$ above preindustrial levels (United Nations, 2018). If we continue muddling through by making small incremental changes, by 2100 global warming is expected to be $4.1^{\circ} \mathrm{C}-4.8^{\circ} \mathrm{C}$ above preindustrial levels (CAT, 2018). The assessment by the United Nations' Intergovernmental Panel on Climate Change (IPCC) (United Nations, 2018) found that even if all the commitments made in the 2015 Paris Agreement are immediately implemented, global warming is likely to be $3.2^{\circ} \mathrm{C}$ above pre-industrial levels, which increases the risk of triggering an irreversible cascade of feedback mechanisms that could accelerate global warming and render the Earth uninhabitable (Vince, 2009).

If we limit warming to $1.5^{\circ} \mathrm{C}$ above pre-industrial levels by 2030 , it might be possible to avoid the worst impacts of climate change. However, this would require "global net humancaused emissions of carbon dioxide $\left(\mathrm{CO}_{2}\right)$ to fall by about 45 percent from 2010 levels by 2030 " (United Nations, 2018). Limiting global warming to $1.5^{\circ} \mathrm{C}$ instead of $2^{\circ} \mathrm{C}$ could prevent $\sim 150$ million air-quality-related premature deaths from 2020 to 2100 (Shindell, Faluvegi, Seltzer, \& Shindell, 2018).

According to the IPCC (United Nations, 2018), it is geophysically possible to limit warming to $1.5^{\circ} \mathrm{C}$ but doing so will require rapid transformative systemic changes in energy, land, urban and industrial systems. The mass mobilisation of the Allies of World War II is often used as an analogy for the scale of collective action and political commitment required to avert the climate crisis (Wallace-Wells, 2019). Wallace-Wells (2019) also noted that the scale of the Allies' mobilisation involved authoritarian demands, such as the nationalisation of industry, widespread rationing and involuntary labour-systemic changes that seem far beyond the reach of current green politics.

Although the solution to the climate crisis is simple, the task of implementing the systemic changes required to avoid its worst effects is extremely complex. While it is theoretically possible to stop emitting greenhouse gases, implementing the changes required to transition to a sustainable society requires political commitment. However, governments are 
often driven by the next election-cycle, and they do not pay sufficient attention to the future. We need resilient political systems designed to meet the needs of the present without compromising the ability of future generations to meet their own needs.

\section{Complexity, Politics and Sustainable Societies}

Responding to climate change will require the design of sociotechnical systems that can address increasingly interdependent environmental, social, political and economic issues. The number of studies in the literature on sociotechnical system design has grown significantly in recent years. Manzini (2017) identified the connection between politics and sustainable societies, claiming that since democracy is a resilient system it is the only political system in which we can imagine a sustainable future society. Manzini (2017, 0:23:30) argued:

Every possible sustainable society has to be resilient... Why? Because it keep [sic] alive a multiplicity of ideas in the same arena... resilience is more or less equal to diversity; coexistence of ideas and practises and ways of doing things.

In Manzini's view, a democratic system is resilient because it can adapt to accommodate the influences of diverse components. Later, Manzini and Thorpe (2018) argued that systems with open and flexible infrastructures should be designed to address unforeseeable encounters and enable local projects to grow and thrive (also see: Bjorgvinsson, Ehn, \& Hillgren, 2010; Thorpe \& Rhodes, 2018).

Similarly, Norman and Stappers (2015) argued that a modular and adaptive approach is best for dealing with complex sociotechnical problems, such as "healthcare, transportation, government policy, and environmental protection" (p. 84). According to Norman and Stappers (2015, p. 93), any attempt to redesign a large, complex sociotechnical system all at once is slated for failure since major projects involve issues related to human psychology and culture that require so many compromises that any future vision is extremely likely to overlook important emerging effects.

Furthermore, Flach (2015) stated that "organizations that aspire to achieve stability in the face of rapid changes and future uncertainties will have to continuously learn and adapt... continuously redesigning themselves in order to make the incremental changes necessary to maintain stability" (p. 98). According to Flach (2012, p. 192), hierarchical, centralised control systems fail to cope with complexity due to "analysis paralysis", since no single agency (e.g. individual or central committee) has enough time to obtain or process all the relevant information. Flach $(2015$, p. 96$)$ noted that the kind of adaptability necessary for long-term stability ultimately depends on the cooperation of many agents including both humans and computers. Consequently, Flach (2012) suggested that the goal of sociotechnical system design is not to eliminate errors due to human variability; rather, it should support resilience by amplifying the human capacity for creativity "so that people can invent solutions in real time to problems that could not have been anticipated in advance" (p. 196).

Manzini, Norman and Stappers, and Flach associated resilience with change to accommodate influences by adapting and making incremental modifications. However, according to Taysom and Crilly (2017), adaptive change is only one of three characteristics of resilient systems. Taysom and Crilly (2017) found that resilient systems may also respond to influences over their lifespans by resisting influences and by recovering from influences. Taysom and Crilly (2017) stated: "A resilient system [is] one exhibiting all three of these characteristics - whether at different times in the system's lifecycle or across different scales" (p. 167). Consequently, scale and timeframe are important aspects to consider when studying the resilience of sociotechnical systems in response to climate change.

The views posited by Manzini, Norman and Stappers, or Flach imply that a political system that is easy to adapt is needed to implement the systemic changes required to avoid the worst effects of the climate crisis. However, almost all states have rigid political systems with 
written constitutions that codify the institutions that structure public power within a state and provide "a stable, neutral framework for the rough and tumble of partisan law and politics" (Waluchow, 2018, para. 19). Arguably, a key difference between a policy and a constitution is that a policy is more often oriented towards issues that fall within the span of a single generation, while constitutions often address long-term issues that are intergenerational.

In fact, only three countries have adaptive constitutions: The United Kingdom (UK), Israel and New Zealand. Adaptive constitutions have an unwritten form and are found in a changing collection of instruments, statutes, norms and conventions. Unwritten constitutions are seen as "an evolving, living entity which, by its very nature, is capable of responding to changing social circumstances and new (and it is hoped better) moral and political beliefs" (Waluchow, 2018, para. 19). For example, New Zealand does not have a written constitution that sets out the basic rules and values under which the country is governed. Much of New Zealand's constitution has the form of unwritten conventions and norms. Consequently, New Zealand's constitutional system is constantly evolving though incremental changes.

Following Taysom and Crilly's (2017) discussion of resilient systems, we might conclude that while most countries have codified their constitutional systems to resist and recover from influences, New Zealand has left its constitutional system open to adapt. Should the rest of the world follow New Zealand's lead and adopt adaptable constitutions to respond to the climate crisis? Or should New Zealand's political system be codified to resist the longterm uncertainty that the climate crisis has created?

We take a constitutional realist theoretical perspective to investigate how public power is constituted in New Zealand (M. S. R. Palmer, 2006a, 2006b). Constitutional realists attempt to understand the whole constitutional system by examining not only the texts that codify constitutional laws but also the structures, principles and conventions that form the ways in which public power is exercised. Constitutional realism and systemic approaches share the commitment to analyse the whole system in context with the aim of synthesising information across disciplines and scales. We draw on cybernetic approaches to model New Zealand's constitutional system as an information processor, and we discuss the implications of our analysis in relation to information flow and feedback.

In the following two sections we describe the historical context of New Zealand's constitutional system in terms of its role in producing national sovereignty and exercising governmental power. First, we describe how New Zealand's founding constitutional document, the Treaty of Waitangi, was established. Then, we discuss the Treaty of Waitangi's place in New Zealand's constitutional system. Finally, we describe the components of New Zealand's government and its proportional representative electoral system.

\section{Sovereignty: New Zealand's Constitutional System in Context}

The ancestors of the Māori sailed from East Polynesia across Te Moana-nui-ā-Kiwa, the Pacific Ocean, to New Zealand where they established the first permanent settlements between 1250 1300 CE (New Zealand Ministry for Culture and Heritage, 2019). They found a vast, forestcovered group of islands, teeming with abundant wildlife. Māori settled New Zealand from the North Cape to the South Island, and they established an active inter-tribal trading system that transported food, clothing and precious stone across the country. Over time, different iwi (tribal groups) formed; members of these tribes trace their origins to the captains and crew of the canoes that made the initial voyage from Polynesia to New Zealand.

There were few encounters between Māori and Europeans until the early 1800s when missionaries first arrived (New Zealand Ministry for Culture and Heritage, 2017). However, by the early 1830s there was a steady increase in British and European migrants (Pākehā), and signs that the French might try to annex New Zealand. The British Crown responded by deciding to establish a colony in New Zealand, ostensibly to the protect Māori, control the unruly Pākehā migrants and secure Britain's commercial interests (New Zealand Ministry for Culture and Heritage, 2019). 
Lieutenant-Governor William Hobson was given the task of securing British sovereignty over New Zealand (New Zealand Ministry for Culture and Heritage, 2019). Hobson travelled from Sydney to James Busby's house in Paihia near Waitangi in the Bay of Islands. Busby was the British resident in New Zealand; over the course of a few days, he and Hobson wrote a draft for a treaty between Māori and the British Crown. Then, overnight on 4 February 1840, a missionary, named Henry Williams, and his son Edward, translated a draft into te reo Māori.

Invitations were sent out to about 100 Northland rangatira (chiefs) to attend a meeting with the chief of the Queen who had come from Sydney to be a governor for everyone (Reynolds, 1990). About 500 Māori met with Hobson in a large tent that sailors had rigged outside Busby's house. Hobson asked them sign te Tiriti o Waitangi/the Treaty of Waitangi, and the chiefs debated the document. Forty chiefs signed the Māori version of the treaty on 6 February 1840. The chiefs believed they had secured protection from being overrun by British settlers and had maintained their chieftainship over their tribes. However, when the British Crown proclaimed sovereignty over all of New Zealand on 21 May 1840, the British believed they had obtained sovereignty over a new colony (Reynolds, 1990).

The difference in the understanding of what had been achieved at Waitangi is due the difference in what the reo Māori and English language versions of the treaty say (Reynolds, 1990). There are at least five known English versions of the treaty, and the Māori version is a translation of a sixth, now lost, early English draft, which differs from the other five versions. Reynolds (1990) explained that, in the English versions, the Queen is to have sovereignty. However, in the Māori version, the chiefs merely cede kâwanatanga, or the right to protect the country. Kâwanatanga was a word invented by the missionaries based on the translation of $k \bar{a}$ wana for governor. Even if kāwanatanga's meaning was uncertain, the second article of the Māori version of the treaty guaranteed the chiefs tino rangatiratanga: full chieftainship of their lands, settlements and property. However, the English version only promised ownership, not chieftainship or Māori sovereignty (Reynolds, 1990).

The place of the te Tiriti o Waitangi/the Treaty of Waitangi in New Zealand's constitutional system often arouses fears that cause division, since political debate in New Zealand tends to focus on the conflicting concerns of New Zealanders-Māori and Pākehā. The fear is that if the treaty texts are included in a superior law constitution, then the treaty would somehow have higher authority than other constitutional norms, such as, perhaps, democracy, and those who benefit from those other norms would, somehow, lose power (G. W. R. Palmer $\&$ Butler, 2018). Furthermore, we cannot assume that there is consensus among Māori on the constitutional place of the treaty because Māori are not a homogeneous people. Mãori refers to a multitude of different iwi, who may hold opposing views, and whose ancestors may have chosen not to sign the treaty.

\section{The Treaty of Waitangi Act 1975}

According to G.W.R. Palmer (1992, p. 234), it is not a question of whether the treaty is constitutional but how it is constitutional. The treaty is already a constitutional document since it affects the system through which public power is exercised in New Zealand. There is constitutional dialogue between the treaty and the other components whenever a component passes legislation, issues a judgement or implements a policy in relation to te Tiriti o Waitangi/the Treaty of Waitangi (G. W. R. Palmer, 1992, pp. 238-244). Through this process, the meaning of the treaty has developed and evolved over time. Consequently, the treaty is a living and powerful part of the law of New Zealand. The Waitangi Tribunal is an institution that provides an important Māori voice in this ongoing constitutional dialogue.

The Treaty of Waitangi Act 1975 established the Waitangi Tribunal to inquire into claims of breaches of the treaty by the Crown as far back as 1840 (G. W. R. Palmer, 1992, pp. 272-275). The Waitangi Tribunal was created with the legal status of a permanent Commission of Inquiry. The Tribunal does not have the formal status of a court and it has no jurisdiction to conclusively determine issues of law. However, for most purposes, it is best considered as a 
way to exercise judicial power that provides Māori with a voice to uphold their rights under the treaty in the face of opposition by the executive branch of the government. Laws are slow to change, and often there are seemingly intractable problems that prevent resolutions. The Waitangi Tribunal has been able to step in and resolve long running disputes.

Parliament has already integrated te Tiriti o Waitangi/the Treaty of Waitangi into New Zealand law, for example when treaty principles were incorporated into the State Owned Enterprises Act 1986 and Conservation Act 1987. Furthermore, when the courts interpret these statutes, they develop a series of principles that can be applied to other cases. However, although the treaty is recognised in numerous statutes, its clauses are inconsistently applied. Some statutes require agencies to "give effect to" the principles of the treaty, others should "have regard to" or "take into account" those principles (G. W. R. Palmer \& Butler, 2018, p. 179). Consequently, the treaty is part of statutory law in some situations, but not others, and its application is inconsistent from one statute to the next. The uncertainty around the treaty's legal status and legal force contributes to the tension surrounding the treaty's place in New Zealand's constitutional system.

The treaty is important not only as a matter law but in terms of its spirit, symbolism and values (G. W. R. Palmer \& Butler, 2018, pp. 193-200). The assertion of sovereignty on behalf of the British Crown in May 1840 depended on the signing of the te Tiriti o Waitangi/the Treaty of Waitangi. Today, the Sovereign Monarch of New Zealand owes her inherited sovereignty to te Tiriti o Waitangi/the Treaty of Waitangi-a connection that holds great symbolic weight. The treaty is a written symbol of commitment to the rights of a minority, the Māori, who ground their claims in their cultural identity. However, this claim is at odds with the constitutional norm of parliamentary sovereignty. Consequently, a novel approach is needed to integrate the treaty into a superior law constitution to recognise both its legal status and the spirit and values that it symbolises.

The fear and tension that surround the treaty are commonly given as the key reasons why New Zealand has not codified its constitution. Palmer and Butler (2018, pp. 174-208) argued that New Zealanders should address the issue of te Tiriti o Waitangi/the Treaty of Waitangi and have a deep national conversation about its place in New Zealand's constitutional system. They propose a superior law constitution that recognises and affirms the treaty rights and obligations to persons of Māori decent. Furthermore, they included a provision that a rigorous public deliberation process must be implemented to work out the detail of the modern meaning of the treaty in a constitutional context. This modular approach facilitates the timeconsuming and complicated task of achieving clarity and certainty about intricate issues of the treaty so they can be considered separately from other constitutional issues. Palmer and Butler's

(2018) approach is underpinned by the distinction between sovereignty and government.

Generally, sovereignty refers to supreme (and perhaps unlimited) power over a domain, while government refers to those persons or institutions through whom sovereignty is exercised (Waluchow, 2018, para. 5). While sovereign power is supreme, the government's power may be limited, since the people can invalidate their government if it exceeds its constitutional boundaries. For most of New Zealand's existence, elections have provided adequate security against government misrule and there has been little need for further checks and balances on the government's power. However, today, New Zealand is larger and more diverse than it was 50 years ago. Now, the country faces systemic changes, such as the climate crisis, which require a more resilient governmental framework to implement the transition towards a sustainable society.

\section{Theory versus Reality: New Zealand's Constitutional System}

New Zealand does not have a single written document called a constitution. However, after a serious constitutional crisis following the 1984 general election, the incoming government reviewed New Zealand's constitutional structures and enacted the Constitution Act 1986. The Constitution Act 1986 delineates some of the major structures and basic rules of government, 
but it contains much less detail than similar documents and it only has the formal legal status of an ordinary statute. Much of the detail about how the key institutions of government are supposed to work is found elsewhere (see: M. S. R. Palmer, 2006b). Approximately 66\% of New Zealand's constitution is legislation, which can be changed by a simple majority. About $15 \%$ is international law that is changed according to the rules of a particular institution, and $11 \%$ is common law that may be amended and developed by the courts to meet changing circumstances. The remaining $10 \%$ is constitutional conventions, which are the unspoken values and customs that are not formalised in any particular way.

Since the framework for New Zealand's constitutional system is spread across many different instruments, it evolves in ways that are difficult to predict. According to M.S.R. Palmer (2006b), in the $20^{\text {th }}$ century more than 50 new elements were added to New Zealand's constitutional system (Figure 1). For example, the upper house was abolished in 1950, the Treaty of Waitangi Act 1975 established the Waitangi Tribunal, New Zealand Bill of Rights Act 1990 was enacted, the Electoral Act 1993 changed the election procedure to proportional representation, and the Supreme Court Act 2003 established the Supreme Court as New Zealand's highest court rather than the Privy Council (UK).

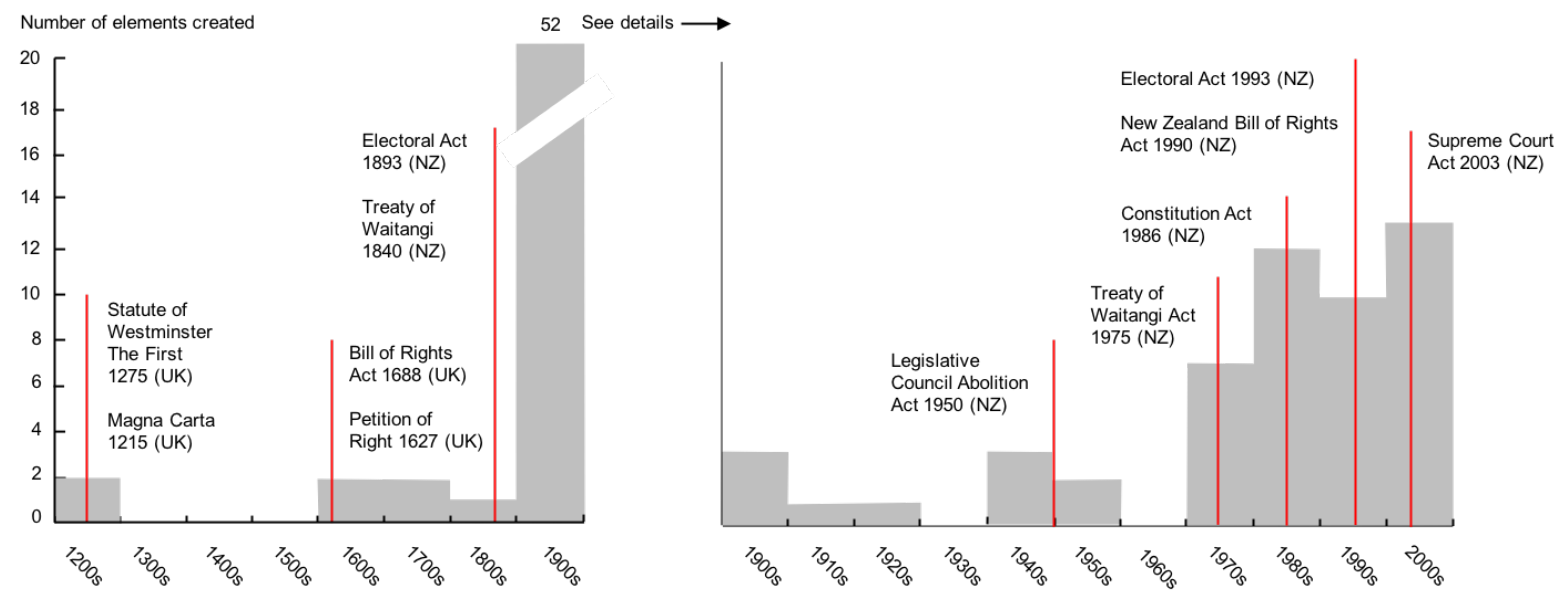

Figure 1. Timeline of New Zealand's evolving constitutional system (Source: M. S. R. Palmer, 2006b).

Furthermore, since New Zealand's constitutional system is constantly evolving, those who are in the position to interpret these elements authoritatively possess significant power (M. S. R. Palmer, 2006b). Consequently, constitutional issues in New Zealand are interpreted by a few powerful office holders (Figure 2, right). In theory, New Zealand's constitutional system separates power between the legislative branch (Parliament), the executive branch (the Cabinet and public service) and the judicial branch (the courts) (Figure 2, left). These institutions act under the authority of the Sovereign, who is represented by the governor-general of New Zealand. In reality, New Zealand's constitutional system is very centralised and streamlined (Figure 2, right). 

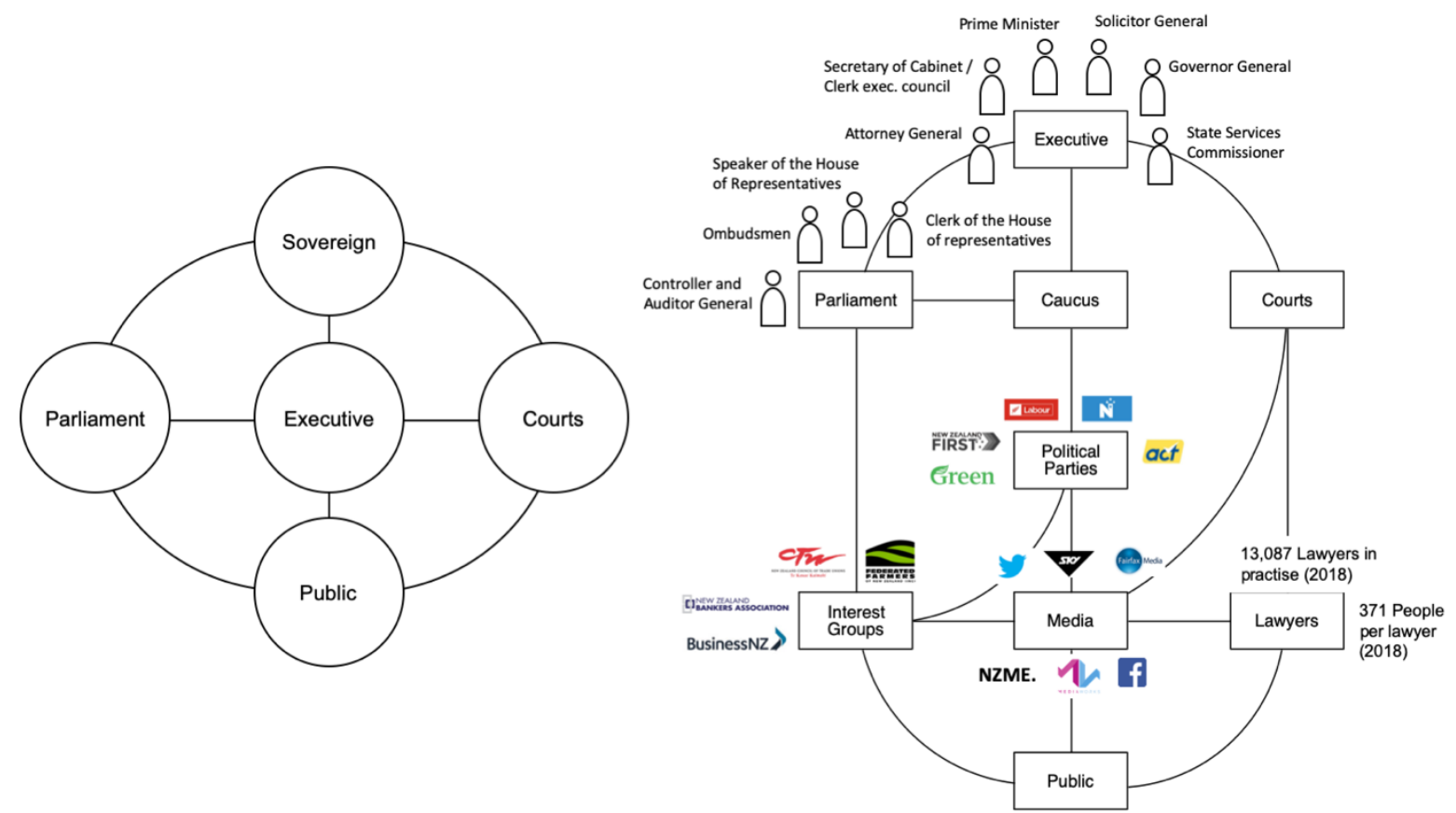

Figure 2. (Left) New Zealand's constitutional system in theory. (Right) New Zealand's constitutional system in reality. (Source: G. W. R. Palmer, 1992; M. S. R. Palmer, 2006).

Until 1996, a single party obtained the majority of seats in the Parliament, thereby electing it to government. Thus, the governing party dominated two of the three branches of government the executive and legislative branches - and, according to the Westminster system, they could overrule the third branch - the judiciary (G. W. R. Palmer \& Palmer, 2004, pp. 9-10). Because the executive branch was formed by a single party in a unicameral legislature operating in a unitary state, the governing party could enact or rescind virtually any law it wished (G. W. R. Palmer \& Butler, 2018, p. 73). The three-year parliamentary term was the primary check against government power. However, in the 1990s, after successive governments enacted radical policies that were often contrary to their election manifestos, public opinion shifted to rein in the government's power. Yet, rather than restructuring that power by implementing more participatory democracy or implementing more robust checks and balances, New Zealanders chose to adapt the electoral system.

\section{Electoral Referendum Act 1993}

In 1993, New Zealand decided by referendum to adapt its electoral procedure to reduce the dominance of the governing party. The aim of the redesign was to amplify the variety of the political parties represented in the legislature to make executive governance messier. New Zealand changed from a plurality-based first-past-the-post (FPP) electoral procedure to the mixed-member proportional (MMP) electoral procedure. FPP is an electoral procedure where parties compete and the winner is the party who wins the most seats. MMP is an electoral procedure where the variety of the electorate is reflected in the composition of the legislative body. In MMP, if a party meets a minimum level of nationwide support or wins an electorate, they are entitled to a share of the seats in Parliament proportional to their share of the nationwide vote. In the 25 years since the first MMP election, more small political parties have entered New Zealand politics, and more women, Asians and Māori have been elected members of Parliament (Maoate-Cox \& Smith, 2019).

In theory, MMP should restrain the executive branch by forcing different parties to slow the rate of action by making governing more complex. Since 1996, the executive branch has 
been formed by a coalition of several parties. Coalitions require parties to work together and compromise. Ministers must convince their own parties as well as their supporting coalition partners to pass a bill into law. Minority parties have some leverage over the majority parties, since it is possible for the supporting minority parties to change their allegiances. MMP introduced more flexible governing arrangements; however, the basic foundational principles remain the same: first, the Parliament ought to be able to legislate as it sees fit; second, the executive branch ought to actively respond to any and all problems that New Zealand society faces (Geddis, 2016, p. 118). For example, coalition governments passed the Foreshore and Seabed Act 2004 and the Canterbury Earthquake Recovery Act 2011 with little debate in the Parliament or input from the public. These Acts show that, even though proportional representation has weakened executive power, coalition governments will still make significant constitutional changes or approve significant expenditures without public input. Arguably, changing the way members of Parliament are selected has not fundamentally changed the streamlined structure through which power is exercised in New Zealand.

The process by which the public selects its representatives in the legislature is similar to the process that design practitioners use to select stakeholders to collaborate in a co-creation workshop. In Evolutionary Stakeholder Discovery, Jones (2018) presented an interesting comparison that pertains to our discussion of New Zealand's democratic system. Jones (2018) described how they sent out invitations over a roughly three-week period using a matrix of $14 \times 7 \times 6$ criteria to identify and recruit 20 stakeholders to participate in a co-creation workshop on the future impacts of urbanism in Southern Ontario (population 12.8 million) for a 20-year horizon. Jones (2018) argued that a group of stakeholders will get the whole system in the room (i.e. be inclusive and representative) if the variety of the participants represents the variety in the society. Jones (2018) noted that if the group of stakeholders in a co-creation workshop is not inclusive and representative, the choice of design methods and processes is irrelevant.

Overall, while we are sympathetic to Jones' argument, in our view, inclusive participation is not a certain and safe path to good outcomes (see: Hyysalo, Jensen, \& Oudshoorn, 2016). As our discussion of New Zealand's change from FPP to MMP elections suggests, the more inclusive procedure for selecting representatives did not produce systemic changes to the centralised structure of the government's power. Certainly, the procedure for selecting deputies is an important aspect of democratic systems; however, we believe it is also necessary to consider how the system works to produce outcomes. In the next section, we draw on the information processing perspective to investigate how New Zealand's constitutional system addresses complexity and exerts control.

\section{Modelling New Zealand's Constitutional System as an Information Processing System}

Systemic approaches frame New Zealand's constitutional system in terms of complexity and control. The more complex a situation is said to be, the more information it is said to have. The system represents how information moves between the public, the legislature and the executive branch. For example, Figure 3 displays a basic model of New Zealand's constitutional system as three components connected by two loops. The first loop connects the public to the legislature and the second loop connects the legislature to the executive branch. The first loop represents the public governance process; the second loop represents the executive governance process.

The 5,000,000 members of the New Zealand public hold a far greater amount of information than the 120 members of Parliament or the 30 members of the executive branch. Since the 30 members of the executive branch do not have enough time to process all the information that is relevant to the public, it is important to ask: How do the components regulate the flow of information between the higher complexity public component and the lower complexity executive component? 


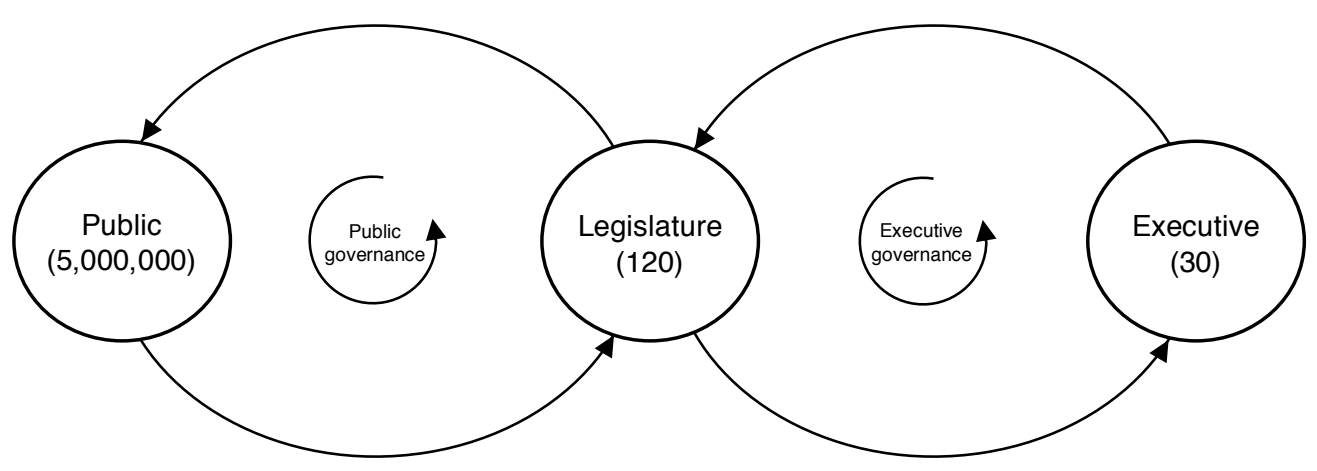

Figure 3. New Zealand's constitutional system modelled as an information processing system.

Defining complexity in terms of information has been at the core of systemic approaches since the 1950s. In his book, An Introduction to Cybernetics, Ashby (1999) proposed a measure of complexity as being the number of states a system may assume in principle (Fischer, 2019; Fischer \& Herr, 2019). Ashby (1999) proposed measuring the complexity of a system by representing each potential state as the value of an input $\left(\mathrm{x}_{1}, \mathrm{x}_{2}, \ldots \mathrm{x}_{\mathrm{n}}\right)$ and the value of an output $\left(\mathrm{y}_{1}, \mathrm{y}_{2}, \ldots \mathrm{y}_{\mathrm{n}}\right)$, then, using combinatory methods, computing the set of possible outcomes. Ashby (1999) called this combined set of potential states the variety of the system. He used traffic light signals to illustrate his concept of variety. As Fischer (2019, p. 794) explained, British traffic lights have red, amber and green lamps, each with two states: on and off. Together, the three signal lamps and two states can assume $2^{3}=8$ different states. However, in their actual traffic control application, the traffic lights only make use of four states: red, red-and-amber, green and amber. The difference between the potential variety of the states and the actual variety of the states is referred to as constraint (Ashby, 1999, p. 127). In the traffic control example, the traffic light's potential variety of eight states is constrained to an actual variety of four states.

A system demonstrates effective control when in "each state displayed by the controlled, there exists exactly one corresponding state on the side of the controller" (Fischer, 2019, p. 795). However, in human activity systems, variety is largely observer-dependent (Fischer, 2019, p. 794). Accordingly, is it more practical to frame variety in terms of the number of distinctions a person can make in a situation rather than the number of possible states (Espejo \& Reyes, 2011, p. 36). Interpreting variety in this way means framing complexity not as a property, but as an attribute that people ascribe to a situation when they distinguish its parts and relationships. For example, new motorists learn to constrain their driving activity based on distinct behaviours that correspond to the four actual traffic light signals. Thus, new motorists are in control when the variety of their driving behaviours matches the variety of the traffic light signals. Ashby's Law of Requisite Variety posits that, for a system to be in effective control, the variety of the controller must be equal to or greater than the variety of the controlled (Ashby, 1999, p. 207; Fischer, 2019, p. 795).

\section{Effective Control and Variety Engineering}

Cybernetic approaches describe the lack of effective control as the imbalance between the greater complexity of the situation the individual encounters and the smaller complexity of the individual's capacity to respond (Espejo \& Reyes, 2011, pp. 50-51). Figure 4 represents situational complexity by the cardinality of the set of distinctions the individual ascribes to the situation he/she faces, and it represents the individual's response complexity by the cardinality of the set of responses he/she can produce. The imbalance of complexities in Figure 4 shows that the individual cannot effectively control the situation since there are events for which, if they were to occur, the individual does not have an appropriate response. 


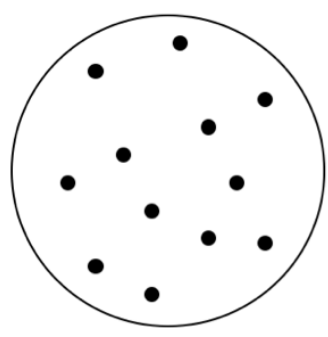

Situational complexity $=12$

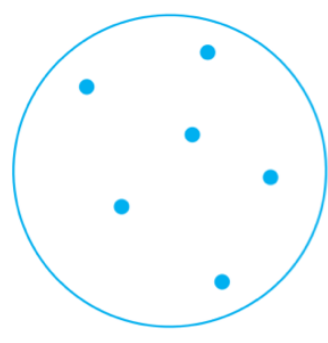

Response complexity $=6$

Figure 4. Imbalance between situational complexity and response complexity (Source: Espejo \& Reyes 2011, p. 51).

This description suggests that an individual might regain effective control by increasing his/her response complexity to match the situational complexity. However, as previously mentioned, Ashby's Law needs to be interpreted in the context of human activity systems because, in most real-life cases, the complexity of the situation is so much greater than an individual's response complexity. Rather than trying to match the complexity imbalance on their own, individuals use complexity management strategies to regain effective control. Figure 5 (left) shows that individuals can regain effective control by redesigning their responses so they may address several distinctions. Now, each distinction is matched by an adequate response. Furthermore, Figure 5 (right) shows that if those distinctions for which we may use the same response were grouped together, we would end up with a partition of the set.
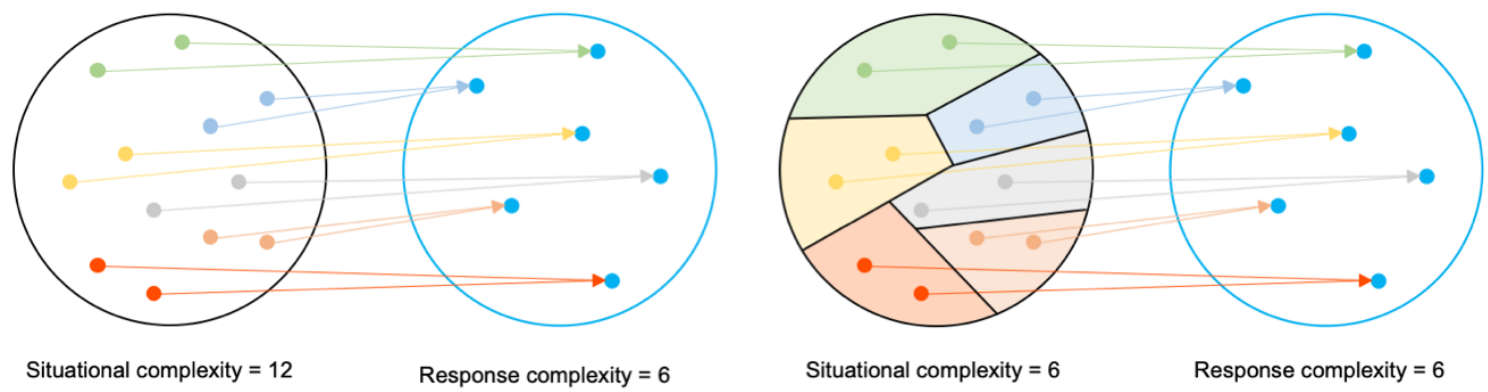

Figure 5. Amplifying response complexity (left) and attenuating situational complexity (right) (Source: Espejo \& Reyes 2011, p. 51-52).

These diagrams demonstrate two strategies that can be used to regain effective control when there is an imbalance in the complexity of a situation. First, we can redesign our responses so we can respond to several distinctions. Second, we can reduce situational complexity by classifying the distinctions we encounter. In general, we can say that a complexity attenuator is any strategy that reduces the number of states in a situation or the number of distinctions that an individual appreciates within it. Conversely, any strategy that increases our response capacity is a complexity amplifier. Furthermore, we can see that complexity attenuators and complexity amplifiers work in pairs. This approach to managing complexity by designing strategies for attenuating and amplifying complexity is what Beer (1979) called variety engineering. Espejo and Reyes (2011, pp. 58-59) identified four types of complexity attenuators with four corresponding types of complexity amplifiers (Table 1). 
Table 1. Complexity Amplification and Attenuation (Source: Espejo \& Reyes, 2011, p. 58-59)

\begin{tabular}{|l|l|}
\hline Types of complexity amplification & Types of complexity attenuation \\
\hline Strengthen response complexity & Weaken situational complexity \\
\hline Increase the resolution of the response complexity & Decrease the resolution of the situational complexity \\
\hline Create new response complexity & Exclude situational complexity \\
\hline Make response complexity time-independent & Make situational complexity time-dependent \\
\hline
\end{tabular}

Cybernetic theory posits that the 5,000,000 members of the New Zealand public have much greater complexity than the 120 members of the legislature or the 30 members of the executive branch. However, this imbalance of complexity has not resulted in New Zealand's constitutional system becoming unviable. New Zealand's constitutional system maintains effective control, and it deals with the difference between the complexity of the public, legislature, and executive branch by implementing strategies for attenuating and amplifying complexity (Figure 6).

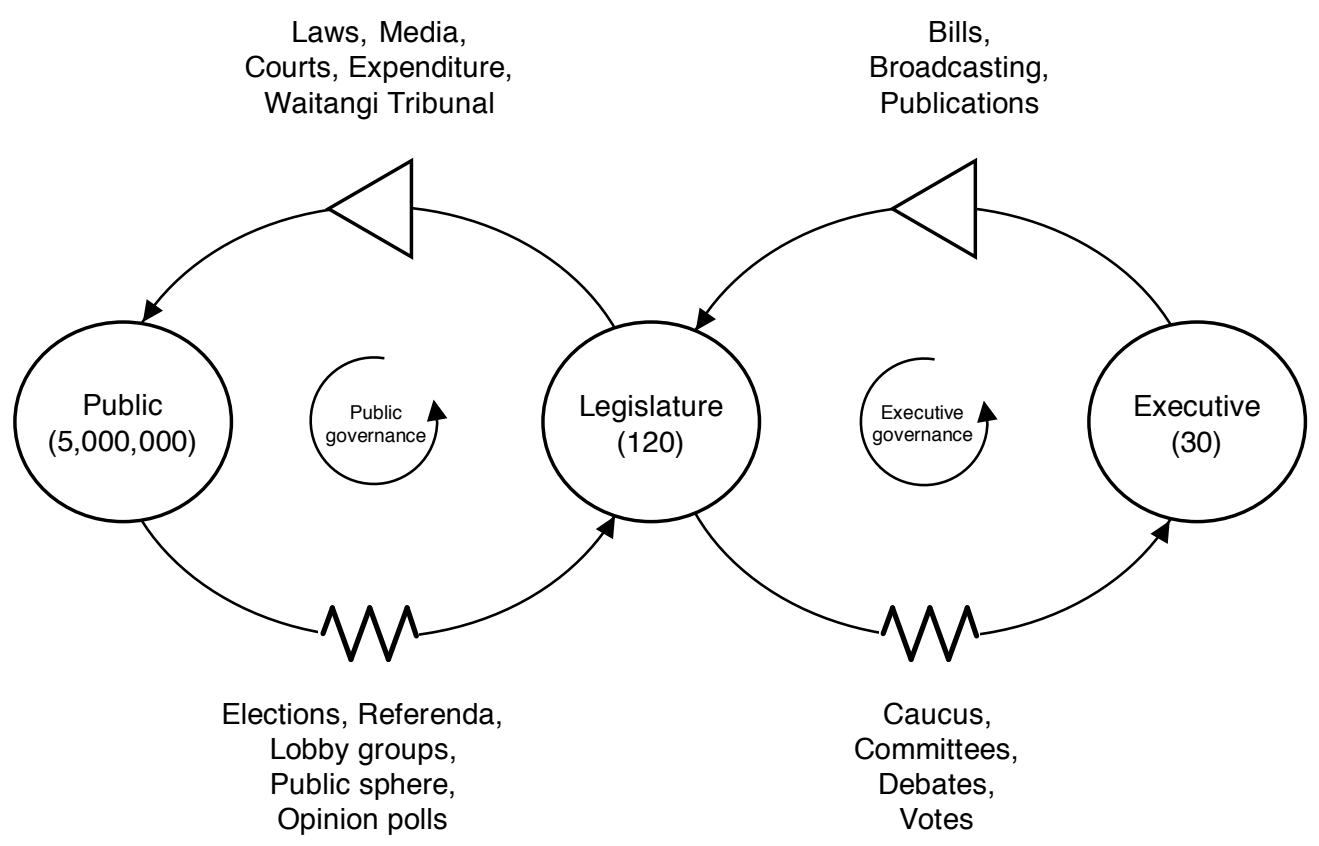

Figure 6. Complexity amplification and attenuation strategies in New Zealand's constitutional system.

\section{Strategies for Attenuating and Amplifying Complexity in Public Governance}

The vast majority of complexity concerning the members of the public does not enter into the public governance loop because most of the time people cope with the complexity of their lives through self-organisation. The most significant complexity attenuating strategy in New Zealand's constitutional system, is the use of elections to select deputies to represent the public 
in the legislature. For example, elections attenuate situational complexity by partitioning the public into electoral districts, by making situational complexity time-dependent via holding elections periodically, by weakening situational complexity via making participation in elections voluntary, and by excluding situational complexity via only allowing votes from members of the public who meet criteria, such as age, residency and so on.

The law of New Zealand is the most significant complexity amplifier in the public governance loop. The legislature is invested with the power to pass Acts of Parliament that set out the basic laws of the land, such as specifying what behaviour constitutes a criminal offence and determining punishments for offences (G. W. R. Palmer \& Butler, 2018, p. 62). The law strengthens response complexity since a single law may apply to many members of the public. For example, the New Zealand Bill of Rights Act 1990 affirms the fundamental rights and freedoms that all New Zealand citizens are entitled to, regardless of their age, ethnicity, culture, religion or sex. Moreover, the courts amplify complexity by interpreting and applying the laws made by enacting legislation since the courts' decisions create a body of precedent called the common law, which ensures that similar cases have similar results, which, in turn, increases the resolution of the law of New Zealand.

\section{Strategies for Attenuating and Amplifying Complexity in Executive Governance}

Only a member of Parliament may hold office as a Cabinet Minister in the executive branch of the government. The Cabinet is the central decision-making body of the executive branch. The Prime Minister chairs the Cabinet and advises the Governor General on which members of Parliament to appoint as the Ministers of the Crown who are responsible for performing the government's activities. In theory, the Prime Minister acts on his/her own; in reality, the Prime Minister's decisions are made only after negotiating and bargaining with their political party. Political parties are a mechanism for weakening and excluding complexity in the legislature. The caucus, the weekly committee meeting of the members of Parliament of a political party, is the mechanism by which a political party controls the executive branch and ensures party discipline in the legislature. The party's caucus weakens situational complexity in the legislature by functioning as an institutional check on the members' actions. The members usually discuss matters of importance within their party's caucus before committing to a course of action; consequently, the caucus attenuates complexity by settling policy differences and promoting party unity.

Policy proposals that require legislation to be implemented must first be drafted into bills. Bills are complexity amplifiers within the executive governance loop. The member of Parliament responsible for a bill introduces it to the House of Representatives. The speech is broadcasted, and copies of the bill are published in the government journals so the bill can be read and absorbed by the members of Parliament and the public before it is debated, amended and passed. New bills amplify complexity by creating new response complexity, and publication in the journals and the broadcasts strengthen complexity and make it timeindependent.

\section{Discussion: Information and Feedback}

The systems approach accepts that we can only partially understand system complexity and behaviour (Taysom \& Crilly, 2017, p. 169). Where the system boundary is drawn determines the structure and function of our system model, the entities we perceive within and beyond that boundary and the spatial and temporal scales we consider. Because the systems approach is perspective-dependent, it demands humility and recognition of uncertainty and ignorance in research (Dovers \& Handmer, 1992, p. 275). Accordingly, the complexity amplification and attenuation strategies we describe here reflect our purposes; they do not provide a complete accounting of New Zealand's constitutional system. While we acknowledge these limitations, we will discuss the implications of information and feedback in New Zealand's constitutional system. 


\section{Information}

Simon (1955, p. 99) emphasised that actual human behaviour is limited by the information humans can access and the computational capacities they possess. Thus, no constitution can give an accurate description of every feature of a government. However, a constitution can define the basic principles, processes and rules that demarcate the institutions and powers of government, and establish the rights of people in their involvement with the state. That said, it is important not to overstate a constitution's efficacy. A constitution may be able to curb power, but it cannot stop abuses of power or safeguard against a society committed to self-destruction.

The key question is not how to manage complexity to obtain all relevant information, but how to design the constitutional system to respond effectively under the conditions of ignorance, uncertainty and unanticipated influences. The systems approach implies that the system should be information-rich, not so much in terms of one institution gathering and analysing as much information as possible, but in terms of the open flow and active use of information (Dovers \& Handmer, 1992, p. 275). Hence, a major problem with New Zealand's unwritten constitution is that it is difficult to find its elements and difficult to understand its precepts. A written constitution that is accessible, available and clear would support the flow and use of information by educating the public about people's rights and responsibilities and by helping them participate in democratic decision-making (G. W. R. Palmer \& Butler, 2018).

In the next 25 years, New Zealand's population profile will become more diverse (MacPherson, 18 May 2017). The Pākehā majority will decline from 75\% in 2013 to about 66\% in 2038. The Māori minority will increase from $16 \%$ to $18 \%$, and the Pasifika communities will increase from $8 \%$ to $10 \%$. The size of the Asian communities will increase substantially from $12 \%$ to $22 \%$ over the 25 -year period, and it will exceed the number of Māori in the mid-2020s. As New Zealand becomes more multicultural, greater respect for diversity and greater protection for individual human rights are needed. However, although New Zealand is an isolated territory in the Southwest Pacific, it is not immune to international political trends.

Populist politics has been on the rise in New Zealand since the 1990s, with antiimmigration and anti-establishment platforms helping various parties increase their proportion of the party vote. A defining feature of populism is anti-pluralism. Chambers (2018) noted: "Populism is univocal. It seeks to speak in the name of 'the people' in clear unambiguous terms. This almost always involves vilifying opposition voices by identifying those as others or enemies, or not authentic members of "the people"" (p. 371). Populism undercuts deliberation and dissent in the public sphere to reduce the public's freedom to oppose, disagree with and criticise power-holders. A populist democratic government maintains effective control by attenuating situational complexity to prevent diverse views from entering the government process.

Deliberative democracy is often presented in contrast to populism. In a deliberative democracy, the government retains popular sovereignty while supporting spaces of debate and criticism in the public sphere on a continuing basis. Deliberative democracy holds public decision-makers to account by making response complexity time-independent. Furthermore, there is evidence that public participation in deliberative mini-publics (such as citizens' juries) successfully integrates different perspectives on complex issues (Mercier \& Landemore, 2012). Moreover, there is evidence that deliberation is effective in involving citizens in reflecting on long-term issues, such as climate change. According to Dryzek and Niemeyer (2019, p. 412):

Studies in the UK and Australia suggest that simply confronting citizens with climate change scenarios induces anxiety that is not conducive to the effective operation of democratic decision making. However, when the same cohort is involved in group deliberation, the very nature of conversation around climate change transforms in ways such as the emergence of a discourse highlighting the need for strong collective action, with far-reaching implications for improving governance and the operation of democratic institutions. 
Deliberative democracy is more often valued on procedural grounds for its intrinsic values, such as freedom, equality, justice and fairness, rather than on instrumental grounds, such as the epistemic quality of its outcomes (Landemore, 2013b, p. 8). The epistemic theory of democracy is probably the variety of democracy that is closest to the instrumental view of an informationrich constitutional system (see: Estlund, 2009; Landemore, 2013b). Epistemic democracy is grounded on the argument that democracy is a valuable decision-making mechanism since it uses the cognitive diversity of people to produce collective intelligence (Landemore, 2011, 2013a; Landemore \& Page, 2014; Mercier \& Landemore, 2012).

\section{Feedback}

Government activity is influenced by the existing political environment; in turn, it shapes subsequent government activity (Pierson, 1993, p. 595). These feedback effects also shape the behaviours and attitudes of the public and the resulting outcomes (Campbell, 2012, p. 334). There is a significant amount of research investigating the effects of micro-level and macrolevel policy feedback. For example, Ingram, Schneider, and deLeon (2007, p. 93) argued that, typically, policy-makers socially construct target populations in positive and negative terms and distribute benefits and burdens to perpetuate these stereotypes. At the micro-level, a policy's design features determine whether democracy appears to be fair or unfair, helpful or antagonistic, an important aspect of life or irrelevant (Schneider \& Ingram, 1997, pp. 5-6). People may come away from encounters with democracy feeling informed and empowered or ignored, isolated or marginalised.

Our model of New Zealand's constitutional system demonstrates feedback at the macrolevel (Figure 6). The double loop system shows that information is not only an output of governance processes, but an important input into them. For example, macro-level feedback processes shift and modify information by politicising and depoliticising issues (Hay, 2007; Wood \& Flinders, 2014). Issues are politicised when they are identified as issues of collective well-being, not private well-being (Wood \& Flinders, 2014, p. 154). Subsequently, they may become the focus of legislative debates and new laws, as well as the responsibility of government departments. Depoliticization is the process of displacing issues from the direct control of elected politicians to the private sphere through delegation, privatisation and denial, so that the issue becomes a matter of private choice (Wood \& Flinders, 2014, pp. 154-155). The feedback effects of politicisation and depoliticization illuminate the New Zealand government's response to climate change over the last 30 years.

The climate change issue was politicised when New Zealand signed the Kyoto Protocol in 1997. However, New Zealand did not ratify the treaty until the Climate Change Response Act 2002 created a domestic legal framework for New Zealand to meet its obligations under the United Nations Framework Convention on Climate Change. The Fourth Labour Government of New Zealand's Climate Change Response Act 2002 proposed a carbon tax; however, it failed to gain the support of its coalition partners, so the tax was withdrawn in 2005 .

The act was amended in 2008 by the Fifth Labour Government of New Zealand to initiate the New Zealand Emissions Trading Scheme (ETS). The ETS was intended to reduce greenhouse gas emissions by requiring polluters to pay the full cost of their actions as a deterrent (G. W. R. Palmer, 2015, p. 130). However, the Fifth National Government of New Zealand depoliticised the issue by passing amendments in 2009 and in 2012 that assigned responsibility for reducing New Zealand's emissions to the private choice of major polluters. Further amendments extended taxpayer subsidies to major polluters indefinitely, which undermined the act's ability to drive emission reductions by putting a price on carbon. Without an effective price signal, the carbon market cannot operate to incentivise changes in behaviour (Parliamentary Commissioner for the Environment, 2012).

The Sixth Labour Government of New Zealand enacted the Climate Change Response (Zero Carbon) Amendment Bill 2019. This latest series of amendments re-politicised the ETS by setting a target to achieve net zero emissions of all greenhouse gases, except for methane 
emissions from agriculture, by 2050, and devised a process for setting progressive emissions budgets to achieve the target on the advice of a special, independent Climate Change Commission (Parliamentary Counsel Office of New Zealand, 2019). Meeting this target will make fossil fuels steadily more expensive to incentivise change. However, the act does not introduce any policies to actually implement emissions reductions; rather, it relies on emissions removals through forestry and the purchase of international carbon credits. While members in opposition to the bill voted for it, they also promised to amend it within their first 100 days if they win the 2020 general election.

Adaptability and incremental change to accommodate influences make a system resilient, but as shown in the frequent amendments to the New Zealand Government's climate change laws, adaptability may be a weakness, since it can create uncertainty and delay. The last 30 years of muddling through has not reduced New Zealand's emissions of greenhouse gases. According to New Zealand's Greenhouse Gas Inventory (New Zealand Ministry for the Environment, 2019), between 1990 and 2017 New Zealand's gross emissions of greenhouse gases increased by $23.1 \%$. But due to the increased volume of timber harvested from New Zealand's plantation forests, New Zealand's net emissions increased by $65 \%$. Although New Zealand's contribution to the world's total greenhouse gas emissions is very small, on a per capita basis, it has the fifth highest emissions of the Organisation for Economic Co-operation and Development (OECD) countries, suggesting that New Zealand is not doing its fair share to limit global heating to $1.5^{\circ} \mathrm{C}$ as required under the Paris Agreement; instead, its actions are consistent with increasing warming by more than $2^{\circ} \mathrm{C}$ and up to $3^{\circ} \mathrm{C}$ (CAT, 2019).

Parliamentary democracy is supposed to debate issues from different perspectives. However, politics can also frustrate the hope of fundamental change when it becomes a kind of controlled spectacle managed by lobby groups and media consultants that turn citizens into passive spectators (Palonen et al., 2019, p. 260). Constitutions should not be used as vehicles to pursue specific policy agendas. Rather, constitutions can lend credibility and impartiality to issues with long-term horizons. Elster (2015) argued: "A rigid constitution can enable citizens to engage in long-term economic planning by removing the chilling fear that the government might confiscate their gains" (p. 442). Without a rigid constitution, governments cannot make credible promises. What security can a law provide if the same entity that enacts it can also repeal it? For example, any piece of legislation introduced by a New Zealand government has, hypothetically, a lifespan of only three years, since that is the stipulated term of a New Zealand government. When a new government is formed, it can repeal virtually any law with a simple majority and party discipline. When constitutional law can be changed by a simple majority decision, there is nothing preventing a government from passing unconstitutional laws. It is a simple two-step process. First, the constitution preventing the desired law is changed, then the law is passed. Thus, the unconstitutional law is now constitutional. This is why written constitutions are made to endure, not indefinitely and not without change, but with a greater lifespan than ordinary legislation.

A constitutional system should be capable of both withstanding or adapting to internal or external influences. In other words, New Zealand's constitutional system needs both a vision of the long-term outcome to move towards, and an adaptable and incremental process for moving towards that outcome.

\section{Conclusion}

This article began by suggesting that responding to climate change requires both technological solutions and political commitment. A resilient sociotechnical system may respond to climate change by resistance, recovery and adaption. New Zealand is one of the only countries in the world whose constitutional system derives its resilience from its adaptability. This article has made the argument that, although adaptability is certainly required, too much flexibility can also become a weakness, since frequent changes can produce uncertainties that delay the ability to respond to complex issues. The value of this perspective is to show that designing for variety 
is not only about intrinsic values, such as inclusivity, but also instrumental qualities, such as better information flow and more effective decision-making.

The issues discussed in this article provide a deeper insight into the nature of politics from the perspective of systems thinking. In particular, we demonstrated that constitutional systems can be modelled as information processing systems that maintain effective control by attenuating and amplifying complexity. This approach contributes to our current understanding of complex sociotechnical system design. The discussion highlights the significance of the effect of feedback in government. In turn, this helps us understand that adaptability is not the only sure path to resilience and effective response. Resistance and recovery also play a role in withstanding or adapting to change.

The contribution of this article has been to generalise systemic design to the domain of constitutional design. Caveats worth mentioning include that the systems approach is perspective-dependent, so it is only possible to partially describe system complexity and behaviour. However, by making these arguments, we hope that we have clarified the issues regarding endurance and adaptably in constitutional design and climate change response.

Luke Feast

Senior Lecturer, PhD

Auckland University of Technology, School of Art and Design

Luke.Feast@aut.ac.nz 


\section{References}

Ashby, R. (1999). An introduction to cybernetics. London: Chapman \& Hall.

Beer, S. (1979). The heart of the enterprise. Chichester: Wiley.

Bjorgvinsson, E., Ehn, P., \& Hillgren, P.-A. (2010). Participatory design and "democratizing innovation". Paper presented at the 11th Biennial Participatory Design Conference, Sydney, Australia.

Campbell, A. L. (2012). Policy makes mass politics. Annual Review of Political Science, 15(1), 333-351. doi:10.1146/annurev-polisci-012610-135202

CAT. (2018). Temperatures. Retrieved 8 September 2019 from https://climateactiontracker.org/global/temperatures/

CAT. (2019). New Zealand. Retrieved 9 December 2019 from https://climateactiontracker.org/countries/newzealand/

Chambers, S. (2018). Afterword: Populist constitutionalism v. deliberative constitutionalism. In G. Orr, H. Kong, J. King, \& R. Levy (Eds.), The Cambridge handbook of deliberative constitutionalism (pp. 370-372). Cambridge: Cambridge University Press.

Dovers, S. R., \& Handmer, J. W. (1992). Uncertainty, sustainability and change. Global Environmental Change, 2(4), 262-276. doi:https://doi.org/10.1016/0959-3780(92)90044-8

Dryzek, J. S., \& Niemeyer, S. (2019). Deliberative democracy and climate governance. Nature Human Behaviour, 3(5), 411-413. doi:10.1038/s41562-019-0591-9

Elster, J. (2015). Explaining social behavior: More nuts and bolts for the social sciences (2nd ed.). Cambridge: Cambridge University Press.

Espejo, R., \& Reyes, A. (2011). Organizational systems: Managing complexity with the viable system model. Berlin: Springer.

Estlund, D. M. (2009). Democratic authority: A philosophical framework. Princeton and Oxford: Princeton University Press.

Fischer, T. (2019). Transcomputability, (Glanville's corollary of) Ashby's law of requisite variety and epistemic processes. Kybernetes, 48(4), 793-804. doi:10.1108/K-11-2017-0457

Fischer, T., \& Herr, C. M. (2019). An introduction to design cybernetics. In T. Fischer \& C. M. Herr (Eds.), Design cybernetics: Navigating the new (pp. 1-23). Switzerland, Cham: Springer International Publishing.

Flach, J. M. (2012). Complexity: Learning to muddle through. Cognition, Technology \& Work, 14(3), $187-197$. doi:10.1007/s10111-011-0201-8

Flach, J. M. (2015). Supporting self-designing organizations [Commentry on "DesignX: Complex Sociotechnical Systems," by D. A. Norman \& P. J. Stappers]. She Ji: The Journal of Design, Economics, and Innovation, 1(2), 95-99. doi:/10.1016/j.sheji.2016.01.002

Geddis, A. (2016). Parliamentary government in New Zealand: Lines of continuity and moments of change. International Journal of Constitutional Law, 14(1), 99-118. doi:10.1093/icon/mow001

Hay, C. (2007). Why we hate politics. Cambridge: Polity Press.

Hyysalo, S., Jensen, T. E., \& Oudshoorn, N. (Eds.). (2016). The new production of users: Changing innovation collectives and involvement strategies. New York and London: Routledge.

Ingram, H., Schneider, A., L., \& deLeon, P. (2007). Social construction and policy design. In P. A. Sabatier (Ed.), Theories of the policy process (pp. 169-189). New York: Routledge.

Jones, P. (2018). Evolutionary stakeholder discovery: Requisite system sampling for co-creation. In S. Barbero (Ed.), Proceedings of Relating Systems Thinking and Design (RSD7) 2018 Symposium (pp. 408-417). Turin, Italy October 24-26, 2018.

Landemore, H. (2011). Democratic reason: The mechanisms of collective intelligence in politics. In H. Landemore \& J. Elster (Eds.), Collective wisdom: principles and mechanisms. New York: Cambridge University Press. 
Landemore, H. (2013a). Deliberation, cognitive diversity, and democratic inclusiveness: an epistemic argument for the random selection of representatives. Synthese, 190(7), 1209-1231. doi:10.1007/s11229-012$0062-6$

Landemore, H. (2013b). Democratic reason: Politics, collective intelligence, and the rule of the many. New York: Princeton University Press.

Landemore, H., \& Page, S. E. (2014). Deliberation and disagreement: Problem solving, prediction, and positive dissensus. Politics, Philosophy and Economics, 14(3), 229-254.

MacPherson, L. (18 May 2017). National ethnic population projections: 2013 (base)-2038 (update) [Press release]. Retrieved 9 December 2019 from www.stats.govt.nz

Manzini, E. (Producer). (2017, 10 May 2018). The politics of everyday life: How to implement a design-based collaborative democracy. Lecture presented at CMU School of Design. Retrieved 10 May 2018 from https://youtu.be/s-KL1zSpr2E

Manzini, E., \& Thorpe, A. (2018). Weaving people and places: Art and design for resilient communities. She Ji: The Journal of Design, Economics, and Innovation, 4(1), 1-10. doi:https://doi.org/10.1016/j.sheji.2018.03.003

Maoate-Cox, D., \& Smith, P. (2019). MMP turns 25: More women, Asian, and Maori MPs. Retrieved 22 January 2019 from https://www.radionz.co.nz/national/programmes/the-house/audio/2018671578/mmp-turns25-more-women-asian-and-maori-mps

Mercier, H., \& Landemore, H. (2012). Reasoning Is for arguing: Understanding the successes and failures of deliberation. Political Psychology, 33(2), 243-258. doi:10.1111/j.1467-9221.2012.00873.x

New Zealand Ministry for Culture and Heritage. (2017). The Treaty in brief: Page 1 - Introduction. Retrieved September 72019 from https://nzhistory.govt.nz/politics/treaty/the-treaty-in-brief

New Zealand Ministry for Culture and Heritage. (2019). Encounters: Page 2 - Pacific voyaging and discovery. Retrieved September 72019 from https://nzhistory.govt.nz/culture/encounters/polynesian-voyaging

New Zealand Ministry for the Environment. (2019). New Zealand's greenhouse gas inventory 1990-2017 snapshot. (INFO 879). Retrieved 19 December 2019 from https://www.mfe.govt.nz/publications/climate-change/new-zealands-greenhouse-gas-inventory-19902017-snapshot

Norman, D. A., \& Stappers, P. J. (2015). DesignX: Complex sociotechnical systems. She Ji: The Journal of Design, Economics, and Innovation, 1(2), 83-106. doi:/10.1016/j.sheji.2016.01.002

Palmer, G. W. R. (1992). New Zealand's constitution in crisis: Reforming our political system. Dunedin: John McIndoe.

Palmer, G. W. R. (2015). New Zealand's defective law on climate change. Victoria University of Wellington Legal Research Papers, (8/2016). Retrieved 19 December 2019 from https://ssrn.com/abstract=2705892

Palmer, G. W. R., \& Butler, A. (2018). Towards democratic renewal: Ideas for constitutional change in New Zealand. Wellington: Victoria University Press.

Palmer, G. W. R., \& Palmer, M. S. R. (2004). Bridled power: New Zealand's constitution and government (4th ed.). New York: Oxford University Press.

Palmer, M. S. R. (2006a). Using constitutional realism to identify the complete constitution: Lessons from an unwritten constitution. American Journal of Comparative Law, 54, 587-636.

Palmer, M. S. R. (2006b). What is New Zealand's constitution and who interprets it? Constitutional realism and the importance of public office-holders. Public Law Review, 17, 133-162.

Palonen, K., Wiesner, C., Selk, V., Kauppi, N., Hans-Jörg-Trenz, Dupuy, C., . . Liste, P. (2019). Rethinking politicisation. Contemporary Political Theory, 18(2), 248-281. doi:10.1057/s41296-019-00326-y

Parliamentary Commissioner for the Environment. (2012). Submission on the Climate Change Response (Emissions Trading and other Matters) Amendment Bill. Retrieved 19 December 2019 from https://www.pce.parliament.nz/media/1396/pce-submission-on-the-climate-change-amendment-bill1.pdf

Parliamentary Counsel Office of New Zealand. (2019). Climate Change Response (Zero Carbon) Amendment Bill. (136-3). Retrieved 9 December 2019 from http://www.legislation.govt.nz/bill/government/2019/0136/latest/LMS183736.html 
Pierson, P. (1993). When effect becomes cause: Policy feedback and political change. World Politics, 45(4), 595628. doi: $10.2307 / 2950710$

Reynolds, T. (1990). The treaty today: What went wrong and what are we doing about it? New Zealand Geographic, (005). Retrieved 7 September, 2019 from https://www.nzgeo.com/stories/the-treaty-todaywhat-went-wrong-and-what-are-we-doing-about-it/

Schneider, A., L., \& Ingram, H. (1997). Policy design for democracy. Lawrence: University Press of Kansas.

Shindell, D., Faluvegi, G., Seltzer, K., \& Shindell, C. (2018). Quantified, localized health benefits of accelerated carbon dioxide emissions reductions. Nature Climate Change, 8(4), 291-295. doi:10.1038/s41558-0180108-y

Simon, H. A. (1955). A behavioral model of rational choice. The Quarterly Journal of Economics, 69(1), 99-118. doi: $10.2307 / 1884852$

Taysom, E., \& Crilly, N. (2017). Resilience in sociotechnical systems: The perspectives of multiple stakeholders. She Ji: The Journal of Design, Economics, and Innovation, 3(3), 165-182. doi:https://doi.org/10.1016/j.sheji.2017.10.011

Thorpe, A., \& Rhodes, S. (2018). The public collaboration lab-Infrastructuring redundancy with communitiesin-place. She Ji: The Journal of Design, Economics, and Innovation, 4(1), 60-74. doi:https://doi.org/10.1016/j.sheji.2018.02.008

United Nations. (2018). Special report on global warming of $1.5^{\circ} \mathrm{C}$. Incheon, Republic of Korea: Intergovernmental Panel on Climate Change Retrieved 19 December 2019 from https://report.ipcc.ch/sr15/pdf/sr15_spm_final.pdf

Vince, G. (2009). Surviving in a warmer world. New Scientist, 201(2697), 28-33.

Wallace-Wells, D. (2019). The uninhabitable Earth: Life after warming. New York: Tim Duggan Books.

Waluchow, W. (2018). Constitutionalism. In E. N. Zalta (Ed.), The Stanford encyclopedia of philosophy (Spring 2018 ed.). Palo Alto, CA: Metaphysics Research Lab, Stanford University.

Wood, M., \& Flinders, M. (2014). Rethinking depoliticisation: Beyond the governmental. Policy \& Politics, 42(2), 151-170. doi:10.1332/030557312X655909 